Maestría en Historia y Memoria

\title{
Que la música no me sea indiferente. La Guerra de Malvinas en el rock nacional (1982-2020)
}

\author{
Don't Let the Music Be Indifferent to Me. The Malvinas War in Argentine \\ National Rock (1982-2020)
}
Que a Música não seja diferente a mim. A Guerra das Malvinas no rock nacional (1982-2020)

\author{
Juan Manuel Cisilino \\ juanmanuelcisilino@gmail.com \\ Universidad Nacional de La Plata, Argentina \\ Fernando Raúl Barrena \\ ferbarrena.fb@gmail.com \\ Universidad Nacional de La Plata, Argentina
}

Recepción: 29 Enero 2021

Aprobación: 28 Junio 2021

Publicación: 01 Diciembre 2021

Cita sugerida: Cisilino, J. M. y Barrena, F. R. (2021).

Que la música no me sea indiferente. La Guerra de

Malvinas en el rock nacional (1982-2020). Aletheia,

12(23), e109. https://doi.org/10.24215/18533701e109
Resumen: En este artículo, analizamos el modo en que se articulan distintas representaciones sobre la Causa Malvinas, la guerra de 1982 y la posguerra en las letras de las canciones de rock nacional, en tanto expresiones de la cultura popular que fijan sentidos y que pueden manifestar ideas coincidentes con las dominantes o, por el contrario, visiones que las cuestionen y pongan en juego su hegemonía. Para ello, tomando al conflicto bélico de 1982 como punto de inflexión, hemos relevado un corpus de veintisiete canciones que explícitamente refieren a la Guerra de Malvinas y sus implicancias, y que han contribuido a articular distintas perspectivas acerca de esta cuestión en el imaginario social.

Palabras clave: Cuestión Malvinas, Guerra de Malvinas, Rock nacional, Ex Combatientes, Dictadura.

Abstract: This article analyzes the way in which different representations of the Malvinas Cause, the 1982 War, and the postwar period are articulated in Argentine national rock songs, as expressions of popular culture that establish meanings and can also manifest ideas in concordance with dominant concepts or, contrariwise, visions that question or compromise their hegemony. To this effect, with the 1982 armed conflict as a turning point, a corpus of twenty-seven songs that explicitly refer to the Malvinas War and its implications has been collected, and their contribution to the articulation of different perspectives about this issue in the social imaginary has been studied.

Keywords: Malvinas issue, Malvinas War, Argentine national rock, Malvinas war veterans, Dictatorship.

Resumo: Neste artigo analisamos a maneira como são articuladas as diferentes representações sobre a Causa Malvinas, a guerra de 1982 e o pós-guerra nas letras das músicas do rock nacional como expressões da cultura popular. Tais representações determinam sentidos e podem manifestar tanto ideias que coincidem com as dominantes ou, pelo contrário, que questionem e coloquem em jogo sua hegemonia. Para isso, coletamos um corpus de vinte e sete canções que explicitamente fazem referência à Guerra das Malvinas e suas consequências que 
contribuíram para a articulação de diferentes perspectivas sobre este assunto no imaginário social.

Palavras-chave: Questão Malvinas, Guerra das Malvinas, Rock nacional, Ex-combatentes, Ditadura.

\section{INTRODUCCIÓN ${ }^{1}$}

La Cuestión Malvinas, desde 1982 hasta la actualidad, se encuentra atravesada por la guerra en la que la Argentina se enfrentó al Reino Unido de Gran Bretaña y a la Organización del Tratado del Atlántico Norte (OTAN). En ese sentido, la guerra del Atlántico Sur ha sido el eje fundamental a partir del cual se configuraron y se configuran las interpretaciones sobre Malvinas en nuestro país. Este conflicto bélico constituye uno de los acontecimientos más importantes de la historia reciente, cuyas secuelas en lo político, en lo geopolítico y en lo social mantienen una insoslayable vigencia. Desde el fin de la guerra se han desplegado relatos, representaciones y discursos construidos desde ámbitos políticos, intelectuales, académicos, culturales, testimoniales y mediáticos. Estos han arraigado determinados tópicos en el imaginario social con la guerra como vértice articulador. Específicamente, en el ámbito de la cultura, han sido numerosas las producciones artísticas, audiovisuales, literarias, periodísticas, musicales, entre muchas otras, que, de un modo o de otro, han tenido como temática central la guerra de 1982.

En este trabajo analizamos cómo se han expresado estas representaciones acerca de la Guerra de Malvinas y la posguerra en un ámbito artístico particular, masivo y de gran influencia en nuestro país: el rock nacional. Indudablemente, la relación entre esta formación cultural y la Guerra de Malvinas ha sido intensa, compleja y contradictoria a la vez. ${ }^{2}$ Más allá de los debates en torno al grado de censura y persecución al movimiento del rock, este género popular se desarrolló bajo un contexto de terror generalizado durante la dictadura cívico-militar de 1976, lo cual, en un primer momento, lo apuntaló como espacio de disputa. Una segunda etapa, "decisiva" para el rock nacional (Lorenz, 2006), comenzó el 2 de abril de 1982, cuando se produjo la recuperación transitoria de las Islas Malvinas y la dictadura dispuso a través de un decreto la prohibición radiofónica y televisiva de música cantada en inglés. Esto implicó un gran impulso a la difusión masiva del rock nativo, el cual "cobró un protagonismo sin precedentes en el país y alcanzó un nivel de circulación social y artística muy movilizador que no decayó con la caída del régimen” (Favoretto, 2014, p. 2). En definitiva, el rock nacional como expresión de la cultura popular ocupó un lugar significativo durante la dictadura y, en particular, a partir del conflicto bélico de 1982. Desde entonces hasta la actualidad, la Guerra de Malvinas ha sido una presencia intensa, contradictoria, escurridiza, polémica e insoslayable en las canciones de nuestro rock.

Lo que buscamos, entonces, es analizar esas huellas de nuestro pasado reciente concebidas como expresiones de la posmemoria (Hirsch, 1997) en tanto construyen una memoria a través de la producción artística y cultural. Siguiendo a Raymond Williams (1988), concebimos a la cultura como un proceso social total en el que entra en juego la hegemonía y la ideología. La cultura, entonces, constituye un campo de disputa; en él se consolidan determinados significados que devienen en cultura y se vuelven hegemónicos, aunque estos se encuentren permanentemente enfrentados por otros sentidos que amenazan su dominación. Como bien destaca Stuart Hall (1984), en la cultura popular está presente el elemento de consentimiento y el de resistencia, es un escenario donde se juega la lucha a favor y en contra de la cultura de los poderosos; hay, en definitiva, lucha por la hegemonía. A la vez, como señala este autor, no hay contenido fijo que se pueda adjuntar al concepto de cultura popular, así como tampoco se le puede adjuntar un sujeto fijo. En ese sentido, podemos pensar al rock nacional como parte fundamental de la cultura popular en nuestro país: es masivo, constituye un territorio de luchas en las que se consolidan relaciones de poder cultural y expresa el carácter intrínsecamente contradictorio de las formas culturales, que se encuentran profundamente atravesadas por 
las contradicciones reales de la sociedad y las luchas por la hegemonía. Estas contradicciones y luchas se cristalizan en representaciones, entendidas, en sentido amplio, como producciones de sentido a través del lenguaje (Hall, 1997). Concebimos esas representaciones como llaves que permiten abrir dimensiones de la configuración cultural (Grimson, 2011) que se ha ido articulando alrededor de Malvinas desde 1982 a la actualidad. ${ }^{3}$

En este punto cabe realizar una breve consideración en torno a la relación entre la guerra de 1982 y la “Causa Malvinas". ${ }^{4}$ En el vínculo entre ambas se articulan dos dimensiones: la disputa de soberanía y la guerra como episodio de la historia reciente en el contexto dictatorial. Por un lado, desde el punto de vista de la problemática de la disputa de soberanía, la Causa Malvinas desnuda y explicita una clara expresión de colonialismo y revela de manera evidente la vigencia de las disputas estratégicas que atraviesan a nuestro país en el escenario global. Por otro lado, desde el punto de vista del pasado reciente, la Causa Malvinas aparece como indisociable del conflicto bélico de 1982 y profundamente atravesada por él y por sus consecuencias. Más allá de la defensa de la soberanía nacional, la principal razón de que se haya configurado como un episodio complejo, controversial e incómodo de nuestra historia se encuentra en que esta guerra fue decidida y dirigida por la dictadura militar que había derrocado al gobierno peronista en 1976. Esto trae aparejada la espinosa complejidad de constituir desde el punto de vista nacional una causa justa y legítima y haber sido, a la vez, una iniciativa de la dictadura.

De acuerdo a cómo se articulan estas dimensiones se construyen las miradas sobre Malvinas en la posguerra. Si bien del análisis de las representaciones de las canciones se desprenderá un marco interpretativo específico, resulta pertinente dar cuenta de cuáles pueden ser consideradas las interpretaciones predominantes que se configuran en los discursos sobre Malvinas. Al respecto, Rosana Guber sostiene que son dos las principales lecturas en las memorias de Malvinas: la heroica y la dictatorial. La primera concibe a Malvinas como "una guerra internacional por un territorio nacional de soberanía pendiente" (2021), en la que, a pesar de la conducción político-estratégica de la dictadura y de la rendición ante Gran Bretaña, los combatientes argentinos, incluyendo a los conscriptos, estuvieron a la altura de las circunstancias y el pueblo argentino defendió una causa justa. La segunda sostiene que "más allá de la justicia de la reivindicación soberana, la Guerra de Malvinas fue un recurso de la dictadura genocida para perpetuarse en el poder” (Guber, 2021); en ese contexto, las fuerzas armadas extendieron las prácticas del terrorismo de Estado en desmedro de los soldados conscriptos, y el pueblo, manipulado por los dictadores, apoyó una guerra absurda. Según Guber, las ideas dominantes se corresponden con la lectura dictatorial. Esta se encuentra "generosamente distribuida en el periodismo, la academia, la cultura, casi todos los círculos partidarios y unas pocas organizaciones de ex soldados combatientes" (2021). Por lo tanto, si consideramos que el concepto de hegemonía es relacional, en el marco de esta disputa la versión dictatorial reviste un carácter hegemónico, en cuanto "se transformó en la versión oficial de la arena pública y, por lo tanto, en la 'forma correcta' de hablar y escuchar sobre Malvinas", mientras que "la gran mayoría de los protagonistas argentinos del conflicto bélico quedó del lado 'heroico' y, por lo tanto, a la defensiva" (Guber, 2021).

Atendiendo al peso específico de estos marcos interpretativos y tomando la guerra de 1982 como punto de inflexión, nos proponemos analizar representaciones sobre Malvinas, la guerra y la posguerra en las letras de las canciones de rock nacional, en cuanto expresiones de la cultura popular que fijan sentidos, revelan huellas de nuestro pasado reciente y pueden manifestar ideas coincidentes con las dominantes o, por el contrario, visiones que las cuestionen y pongan en juego su hegemonía. ${ }^{5}$ Para nuestro análisis hemos relevado un conjunto de veintisiete canciones ${ }^{6}$ que refieren explícitamente a la Guerra de Malvinas y sus implicancias, y que han contribuido no solo a reproducir, sino también a configurar las representaciones en el imaginario social. ${ }^{7}$ La selección de este corpus ha pretendido ser exhaustiva, aunque no definitiva. Para alcanzar una mayor profundidad en el análisis, nos proponemos abordar las representaciones y sentidos expresados en las letras de las canciones en torno a tres ejes: 1) cómo se concibe la Causa Malvinas, el conflicto bélico de 1982 
y la posguerra; 2) la figura de los ex combatientes y la de los militares de la dictadura; y 3) el papel de "la sociedad" y "el Estado". ${ }^{8}$ Esto nos permitirá examinar en qué medida y en qué sentidos estas representaciones dialogan, se articulan o se contradicen con las interpretaciones descriptas anteriormente.

\section{MaLVinas EN LAS CANCIONES: UN ANÁLISIS DE REPRESENTACIONES}

\section{La guerra, la plaza y las rancias cunas de poder}

Relacionado con la lectura dictatorial (Guber, 2021), el conflicto bélico de 1982 puede concebirse como la instrumentación de una causa percibida socialmente como justa en beneficio político de la dictadura. Esto se manifiesta en numerosas canciones y se refiere al contexto en el que se produjo la guerra. "Han sacrificado jóvenes terneros para preparar una cena oficial", sentencia la emblemática canción de Virus de 1982, "El banquete". Sintetiza, a través de la analogía, una mirada sobre la Guerra de Malvinas como una maniobra de la dictadura para limpiar su imagen.

El 16 de mayo de 1982 se organizó el Festival de la Solidaridad Latinoamericana, con la participación de la mayoría de los músicos más populares del rock argentino y bajo el lema Mucho rock por algo de paz ${ }^{9}$ (Pujol, 2007b). En ese contexto, Virus, banda muchas veces reducida al ámbito de la superficialidad por otras corrientes del rock, tuvo una posición firme: fue el único grupo invitado que se negó a participar. De allí la ironía que recorre la canción sobre la invitación a un "gran banquete", donde las víctimas son los jóvenes conscriptos que fueron sacrificados como "carne de cañón" de una dictadura repudiada por años de represión y de una política económica lesiva, ya sumamente cuestionada por luchas obreras y populares. En ese sentido, la canción deja una advertencia: "Pero ¡cuidado! / Ahora los argentinos andamos muy delicados / de los intestinos...”.

Esta mirada predomina en varias canciones: "Los jefes de los chicos / toman whisky con los ricos, / mientras los obreros hacen masa / en la Plaza como aquella vez", canta Charly García en la también irónica "No bombardeen Buenos Aires" (1982). Allí pueden verse entrelazadas miradas sobre la dictadura, los soldados y los obreros. La dictadura defiende los intereses de los ricos y está encabezada por el general Galtieri, sobre quien pesa la etiqueta de "borracho". Los combatientes son señalados como "los chicos", figura persistente en el imaginario sobre los ex combatientes y cristalizada en la película Los Chicos de la Guerra (Tenembaum y Kamin, 1984). La referencia a la plaza llena de obreros puede interpretarse de diferentes modos. Como antecedente histórico, acentuado por la distancia del pronombre demostrativo, puede referirse al $17 \mathrm{de}$ octubre de 1945. Como antecedente inmediato, puede vincularse a la movilización, duramente reprimida, encabezada por la Confederación General del Trabajo (CGT) el 30 de marzo de 1982, para ilustrar la aparente contradicción con el apoyo que, pocos días después, recibió la recuperación de las Malvinas. ${ }^{10}$

En contraposición a ese gran apoyo, Charly García da cuenta con humor de la visión de otra parte de la sociedad: la guerra se presenta como ajena a los argentinos, pertenece a las "rancias cunas de poder", mientras que la figura del ciudadano inocente aparece atravesada por la culpa de no poder "comer un bife y sentirse bien”, y su preocupación principal, en todo caso, se reduce al riesgo de ser bombardeado en el continente, amenaza que circulaba por aquel entonces. A la vez, se manifiesta una contradicción entre el "enemigo" inglés y la adoración por su cultura tan cara al rock: "Los pibes de mi barrio se escondieron en los caños / espían al cielo / usan cascos, curten mambos / escuchando a Clash". Frente a la censura de la cultura inglesa por parte de la dictadura, la única alternativa era escuchar a la BBC de noche.

Esta idea de ajenidad, que exime de responsabilidad a la sociedad civil, también se manifiesta en la canción de Fito Páez de 1985, "Decisiones apresuradas”, donde, a la vez, se refuerza la visión que sostiene el carácter irracional que habría atravesado la decisión de la dictadura de ir a la guerra: "Cocaína / Alguien decide por el país / no me culpen, no estoy dispuesto a morir sobre un crucifijo / tiran y tiran líneas / aspiran. / Generales 
mataron a media generación / una guerra no es un negocio ni una ilusión / una guerra es sangre / Vienen y van al baño / Y toman apresurados la decisión / Y no entiendo, yo aquí no entiendo nada”. Para acentuar esto, en la grabación se escucha la voz del actor Norberto Campos imitando la voz del general Galtieri, quien es llamado "general Alcoholtieri". Sin dudas esta es la figura predominante para caracterizar metonímicamente al dictador y, por extensión, a la dictadura, lo que refuerza lo irracional de lo que se puede considerar desde esta mirada una "aventura militar".

\section{Tan lejos de casa}

En las canciones analizadas hasta aquí se enfatiza el carácter absurdo de la guerra. Un caso singular es el de "Reina Madre" (1983) de Raúl Porchetto. En su letra el enunciador asume la voz de un soldado inglés que se despide de su madre para ir a combatir por orden del "Reino" debido a que "unos salvajes osaron molestar el orden imperial y pagarán”. Primero, el inglés se siente superior, “somos distintos, somos mejores”, pero luego expresa su desconcierto al ver que los soldados argentinos "son iguales a él" y "aman este lugar, tan lejos de casa, que ni el nombre recuerdo". Es decir, se opera un desplazamiento en su perspectiva: su punto de vista inicial está teñido por la mirada imperial británica, pero este se va modificando al advertir el sentido que tiene esta lucha para los combatientes argentinos.

Entonces, mientras "la Reina pasea en los jardines / y el sol besa las rosas, / la vida le sonríe, / el Parlamento cuida que todo siga igual, / que nada perturbe su calma”, el soldado inglés se pregunta "¡Por qué estoy luchando? ¿Por qué estuve matando?”. La "Reina Madre” es nada menos que Isabel II, monarca de Gran Bretaña, quien luego de enviar fuerzas militares "tendrá una premier de cine / de un director famoso, / que cuenta los flagelos / de la guerra y los hombres / y ella se emocionará, / y aplaudirá su gran final”. Lo disruptivo de esta canción reside en que al mismo tiempo que la guerra se vuelve absurda para el bando británico, adquiere sentido para el argentino.

Resulta notable, a su vez, que cuando se construye la perspectiva del soldado inglés se proyecta en ella las mismas representaciones que se configuran en torno a los soldados argentinos (desarrolladas más adelante). Lo que difiere, en todo caso, es el sentido que adquiere la lucha para cada cual. Del mismo modo, la construcción de las figuras de la Reina y de Galtieri obedecen a esta lógica, pero en tanto gobernantes inescrupulosos que banalmente dirigen la guerra persiguiendo intereses espurios. Asimismo, resulta llamativa la referencia a la monarca, en lugar de a la primera ministra británica, Margaret Thatcher

\section{No hay peor mal que el propio hombre}

Las miradas hasta aquí analizadas sostienen la existencia de dos bandos enfrentados. En cambio, la guerra puede ser vista en sí misma como una tragedia humana, tal como se expresa en la canción "Deseando destruir y matar" (1985) de V8. Para el ser humano no hay peor mal que el propio hombre, cuyo accionar engendra "codicia, ambición e injusticias / que culminan en agresión, / fuerza demencial, que domina / al mundo de hoy”. La gente "padece por un ideal / mil hombres se enfrentan sembrando / destrucción total”. El sinsentido de la guerra no distingue bandos ni responsabilidades. En la misma dirección, Walter Giardino, en "Gente del sur" (1988) de Rata Blanca, se pregunta: "No sé muy bien / cuál fue la gloria / en esta guerra del sur".

Algo similar ocurre en la "La isla de la buena memoria" (1983) de Alejandro Lerner, donde prevalece el desamparo humano frente al horror de la guerra: "No hay mal que no venga al Hombre, no hay un Dios a quien orar, / no hay hermanos ni soldados, ya no hay jueces ni jurados, / sólo hay una guerra más”. Del mismo modo, "Maniobras de Guerra" (2004) de Tren Loco, como señala Federico Lorenz (2006), aborda la contienda vinculada al descrédito de la dictadura: "El sacrificio de los jóvenes en las islas ha sido en vano. Los muertos en las islas se emparentan con los muertos por la represión." (p. 293). La canción finaliza con 
una afirmación rotunda y definitiva sobre la Guerra de Malvinas: "Nada para rescatar, sólo cadáveres para contar”. En el mismo sentido, refiriéndose al hundimiento del Crucero General Belgrano, que produjo la muerte de 323 argentinos y que ha sido denunciado como un crimen de guerra británico, Patricio Rey canta en su inédito "Cuá Cuá Amén" (1987): "Me acabo de enterar de un fiero crimen / de un rico embarque de sangre de Satán"; con ironía, sugiere lo absurdo de tantas muertes: "Mi conciencia estaba lista / cuando la carne explotó. / (...) Los deben estar venciendo... / ¡Dios siempre tan imparcial!”.

A diferencia de aquellas visiones donde el conflicto armado es concebido como una aberración en su dimensión social, el manifiesto antibelicista "No quiero ir a la guerra" (1998) de Flema refuerza el profundo escepticismo, pero desde una perspectiva individual. Denuncia la hipocresía de los gobernantes que "mandan a los chicos a que los masacren" y descree de las fronteras trazadas por los Estados: "Yo creo en la frontera / que rige mi cerebro / y si quieren guerras / que peleen ellos”. Este rechazo al enfrentamiento no está tan motivado por el miedo o la cobardía, como por la desobediencia individual: "No quiero ir a la guerra / no quiero que me maten / porque soy muy joven / para ser un cadáver".

\section{Un banderín agitar frente a un ejército popular}

No todas las canciones interpretan a la guerra como absurda. En la canción de Víctor Heredia, "Aquellos soldaditos de plomo" (1983), el enunciador, rescatando el fuerte contenido belicista que influyó en muchas generaciones de argentinos, se reprocha a sí mismo que "De pequeño yo tenía un marcado / sentimiento armamentista; / tanques de lata, de cromo y níquel / y unos graciosos reservistas de plomo, / a mano pintados, / con morriones colorados / que eran toda una delicia para mi mente infantil... / yo me creía, como creía en el honor...”. El lamento se debe a la crítica hacia quienes han empleado esos símbolos para fines nefastos, manchando esos valores; por eso se pregunta: “qué nos pasó, cómo ha pasado? / ¿Qué traidor nos ha robado / la ilusión del corazón? / Creo que quiero cerrar los ojos / para no ver los despojos de lo que tanto / amaba entonces".

Sin embargo, el final escapa al pesimismo: más allá del uso injusto de los símbolos patrios y militares que las dictaduras llevaron a cabo, es posible aún mantener la esperanza de que "vuelva el bruñido del bronce, / que se limpien las banderas; / yo quiero ser una fila entera de soldados desfilando / y todo un pueblo cantando con renovada pasión. / Quiero de nuevo el honor / aunque no existan victorias, / quiero llorar con la gloria de una marcha militar, / y un banderín agitar, frente a un ejército popular”.

\section{El TIAR fue la mentira que algunos se creyeron}

En pocas oportunidades las canciones relevadas hacen alusión a la dimensión internacional de la guerra del Atlántico Sur. Una excepción es el tema de Los Violadores, “Comunicado 166” (1985):

Se ha perdido la batalla / por falta de armamentos. / La CEE [Comunidad de Estados Europeos] junto a la NATO [OTAN] / nos hicieron el bloqueo. / Latinoamérica unida, gritó el pueblo entero. / El TIAR [Tratado Interamericano de Asistencia Recíproca] fue la mentira que todos se creyeron. / (...) De qué sirvió esa unión / que no logró la fuerza / y no hay fuerza cuando no hay inteligencia, / porque EE.UU. ha demostrado / que Occidente está en sus manos. / Recién nos dimos cuenta / cuando fuimos traicionados, vapuleados, pisoteados".

De esta manera, la canción expone la disputa de intereses geopolíticos que se pusieron en juego durante el conflicto y da cuenta de los supuestos con que la Junta Militar encaró la guerra: Estados Unidos había prometido mantener la neutralidad y oficiar como árbitro en una mesa de negociaciones con el Reino Unido (incluso algunas interpretaciones sostienen que le habría dado una "luz verde" a Galtieri para llevar adelante la operación). En ese sentido, Los Violadores ponen de manifiesto cómo el incumplimiento del TIAR por parte de Estados Unidos, que respaldó a Gran Bretaña, y la solidaridad latinoamericana, que la dictadura decidió 
no aprovechar, son dos aspectos claves para entender el desenlace de la guerra de 1982. Por su parte, Don Lunfardo y el Señor Otario (DLSO) en "Antihéroes" (1999) también aborda la dimensión internacional del conflicto, denuncia el doble juego del país del norte y la complicidad de la dictadura chilena: "Y un árbitro yanqui dirigió el partido / con la camiseta del pirata inglés / pero esto no es todo, mis queridos amigos, / con la número 9, Augusto Pinochet”.

\section{Por no querer a la Patria o por quererla demasiado}

Como ya hemos mencionado, el carácter de la dictadura que decidió y dirigió el conflicto ha tenido una fuerte incidencia en las interpretaciones sobre la Guerra de Malvinas. La figura de Galtieri como un "borracho" que mandó a morir a jóvenes argentinos ha sido una representación persistente. Esto ha reforzado no solo el carácter absurdo de la guerra por Malvinas, sino también su naturaleza genocida orquestada por los altos mandos que venían siendo responsables por la muerte y desaparición de decenas de miles de argentinos: "querer matar a tus hijos / es para que duela años la sangre. / Ayer por no querer a la patria, / y ahora por quererla demasiado", dice León Gieco en "Para la vida” (2006).

Entre las interpretaciones que sostienen el carácter absurdo de la guerra, hay perspectivas que niegan la importancia del archipiélago y refutan la legitimidad del reclamo de soberanía por parte de la Argentina. Es el caso de algunos intelectuales que consideran que la recuperación de las Malvinas el 2 de abril fue una "invasión", tal como manifestaron en una carta publicada en La Nación, donde sostuvieron que esta debe ser "condenada sin cortapisas" ("Intelectuales cuestionaron", 2012) y reivindicaron el derecho a la autodeterminación de los isleños ("Una visión alternativa”, 2012). Esta idea de "invasión" parte del supuesto de que las Malvinas no pertenecen a la Argentina. Algo semejante puede entreverse en los versos de la ya citada "Maniobras de Guerra" (Tren Loco, 2004): "Con esos putos números la vida te amarraron / A un destino lejano, un extraño país. / En un frío lodo olvidado, los cuerpos amasijados / 2 de Abril, día negro nacional”. En lo destacado de estos versos se refuerza una representación que enfatiza el carácter distante, extraño y ajeno de las Islas Malvinas para los argentinos, al punto de ser otro país.

Por otro lado, como hemos visto, están las perspectivas que reducen la guerra a la decisión de un general alcohólico con el objetivo de perpetuar a esa dictadura en el poder: "Fue el alcohol / de una bota formal / el que quiso ver mis sueños quebrar", canta Callejeros en "No volvieron más" (1998), enfatizando que el único sentido de la guerra fue habilitar una maniobra de la dictadura: "tu bandera te empezó a traicionar / circo y pan como siempre fue acá". En una dirección similar, aunque reivindicando la lucha por la soberanía, en "Malvinas" (2000) Cielofinal se cuestiona: "No sé si es justo, Patria mía, / que escondamos las heridas, / han engañado a nuestro pueblo / los traidores y la mentira".

En estas visiones, los altos mandos de la dictadura se convierten en los únicos responsables por las muertes de combatientes argentinos, invisibilizando la responsabilidad británica: “¡Amor a la Patria! ¡Tomen sus armas! ¡A matar! ¿¿Dónde está el enemigo? ¿Lo borraron? ¿Lo cambiaron?” ("Maniobras de Guerra”, Tren Loco, 2004). El repudio hacia la dictadura es tan implacable que Ciro y los Persas (2012) sentencia en "Héroes de Malvinas": "La basura indefinible de esa escoria / que soñó con perpetuarse en la Rosada / Debería haber sido inmediatamente por sus pares / en la gran plaza de Mayo fusilada”.

\section{Nada me dejó la Patria}

La rendición argentina el 14 de junio produjo un cambio profundo en la situación política. El espacio público copado por movilizaciones masivas ya no tuvo marcha atrás. ${ }^{11}$ La dictadura, ya muy debilitada, comenzó a organizar su retirada y se impuso, todavía con el gobierno militar, ese proceso con implicancias políticas, económicas, sociales, militares y culturales que se ha denominado desmalvinización. ${ }^{12}$ 
El desamparo estatal al que fueron arrojados los ex combatientes ni bien terminado el conflicto bélico se manifiesta en la canción "Soy del 2 de abril" (1994) de Attaque 77: "Sigo besando la espalda que me dio el Estado. (...) / Nada me dejó la patria, me fui quedando a un lado / estoy harto de vivir para sobrevivir”. Como correlato, las representaciones sobre el papel de "la sociedad" ante quienes volvieron de la guerra se manifiestan en las canciones como expresión de abandono e indiferencia: "Muchos de los que me amaron me dejaron a un costado / el resentimiento me enfermó y ya no pude salir" (Attaque 77, 1994). Esa actitud de la sociedad ante el ex combatiente aparece como aún más dura y contundente que la propia experiencia bélica: "Puede más la indiferencia de tu gente/ que la bala más voraz del enemigo" (Ciro y los Persas, 2012).

Estas representaciones de actitudes sociales indiferentes reaparecen a través de metáforas referentes al fútbol: "Nos prendimos a jugar un Mundial / y después nadie supo saltar / por los sueños que se hundieron allá" (Callejeros, 1998). El fútbol se presenta como una ilusión, un falso desagravio frente al dolor de la guerra: "La mano de Dios / no apagó mi dolor / gritan los antihéroes del '82" (DLSO, 1999). Por el contrario, en "Qué es Dios" (2008) de Las Pastillas del Abuelo, el fútbol (y en particular los goles de Diego Armando Maradona frente a los ingleses en 1986) representa una incruenta reparación:

Convirtió la red en tierra / del balón hizo palomas / que aterrizaban su paz / en la Isla Soledad / borrando una absurda guerra (...) Premio Nobel de la Paz / desde México a Fiorito/ de Malvinas a Inglaterra / este loco diez bajito / llenó de risas la tierra. / Llantos y risas de madres / viendo en el diez al compadre / genera risa latente / su risa en todas las fotos / de los hijos combatientes.

Por su parte, la posguerra se representa en la mirada del ex combatiente como una continuación de la guerra: "Estoy en guerra desde que acabó la guerra / vendiendo recuerdos que nadie quiere recordar" (Attaque 77, 1994). Aparece entonces en el ex combatiente un rechazo a esa mirada lastimosa atribuida a la sociedad: "Yo no quiero mendigar, yo me lo quiero ganar, / todos pasan y me miran con lástima, no me mires más, no me mires más" (Attaque 77, 1994), exige el ex soldado, con agencia, frente a una sociedad que lo margina. De igual modo, Rata Blanca canta en "Gente del Sur" (1988) que "La sociedad sigue mostrando que es solamente parte del mal” y agrega Fito Páez (2013): "hoy nadie nos ama, no hay más amigos”. Como figura paradigmática de la exclusión social de los ex combatientes, "loquitos del casco" fue un mote que moldeó las representaciones sobre ellos: "A un loco de la guerra nadie le quiere dar trabajo, / será que hay demasiados trabajando en el país / conduciendo patrulleros, pueblos, taxis, colectivos... / Todo el mundo tiene su factor de poder, / yo quiero también" (Attaque 77, 1994). Con estos versos finales, las representaciones que se configuran en la canción enfatizan la resistencia de los combatientes al "olvido".

\section{Menos héroes muertos en el frente que en el campo de batalla del olvido}

Hay canciones en las que emerge una representación minoritaria ante esa sociedad que olvida. En referencia a los sobrevivientes del Crucero General Belgrano, al que "hirieron con espada de traición certera", Tren Loco en "Acorazado Belgrano" (2008) canta que "El valor/ de los sobrevivientes / del Belgrano/ es más fuerte y persistente / que el olvido urbano / y mezquino / de los que miran por TV". El mismo reproche se manifiesta en "El Visitante" (1999) de Almafuerte: "Olvidar / yo sé bien que no podés / como la sociedad olvida / que fuiste obligado a marchar, / en su defensa. (...) / Fui elegido, para cantarte / por quienes quieren olvido restarte / grave pesado mas no inconsciente / yo te lo mando ex combatiente". De esta manera, se articula una visión que reivindica el sentido de la lucha de los combatientes en defensa de una sociedad que los ha olvidado. Lo mismo ocurre con "Memorias de la Guerra" (1994) de Embajada Boliviana: "Y en tu corazón, aquellas vidas, / que pelearon por Argentina, / igual que vos, igual que él... / Memorias de la guerra, de una noche oscura / y de claras estrellas, y de una blanca luna / y de cuerpos que murieron defendiendo a su bandera”. Retomaremos estas visiones, que se emparentan con las ideas de la lectura heroica (Guber, 2021), más adelante. 
Frente a una sociedad refractaria, la posguerra, para el ex combatiente, aparece como un auténtico tormento: "Recordando el mal momento / atrincherado en tu habitación; / soledad, humo y penumbras / despertares de ultratumba. / Apocalipsis del sustento interior / andar sin encontrarle alivio al tormento / desesperante, mórbida aflicción / del visitante y su castigo" (Almafuerte, 1999). La referencia a "la guerra después de la guerra" reaparece en estos versos. El horror del trauma palpita ahora en el interior del ex combatiente, la desolación del escenario bélico se desplaza a la oscuridad de la habitación, donde emerge la figura fantasmal de los caídos. ¿Quién es, entonces, el visitante? ¿Cuál es su castigo? ¿Es acaso el compañero muerto o es él mismo convertido en alteridad para la sociedad?

La reclusión y el aislamiento se representan también en la ya citada "Memorias de la guerra" (Embajada Boliviana, 1994): "Hoy tú sientes que estás mal, / tu corazón no para de gritar / y tus oídos siguen escuchando / disparos muy lejanos que quedaron en tu mente. (...) / Y en la cabecera de tu cama / una medalla de condecoración. / Y temés por enloquecer / y tienes miedo, miedo al amanecer / miedo a las cosas, miedo a las calles". Nuevamente, reaparece el trauma confinado al espacio interior; las calles, el afuera, lo público forman parte de un territorio vedado. La posguerra aparece entonces como un período pesadillesco en el que el honor se transfigura en dolor por las consecuencias, la tragedia y el olvido: "Madre, ponme en la chaqueta las medallas / los zapatos ya no me los puedo poner / mis dos piernas se quedaron en Malvinas / el mal vino no me deja reponer de la nítida y oscura pesadilla" canta Fito Páez en la extensa "La casa desaparecida" (1999). El título opera como metáfora de la Argentina como una nación con destino incierto.

Si bien dentro del entorno familiar del ex combatiente la referencia a la figura materna es la que cuenta con más presencia en las canciones analizadas, dos temas, "La canción del soldado y Rosita Pazos" (Páez, 2013) y "Amor suicida" (2 minutos, 1994), toman la figura de la novia para representar el conflicto de una parte de la sociedad que no olvida. Las situaciones difieren. En la canción de 2 minutos la muerte del amado en la guerra sumerge a la protagonista en la depresión, que encuentra como único consuelo el suicidio: "Me encontré una chica en la plaza / estaba llorando, yo no sé por qué (...) / Caminó unos pasos y un arma sacó / y yo le pregunté y ahora qué vas a hacer, / no me respondió y el gatillo ella apretó. / Ella se voló la cabeza por su viejo amor. / Ella se voló la cabeza por su muerto amor". Por su parte, en el tema de Fito Páez el combatiente ha regresado pero el amor de su novia no alcanza para rescatarlo, se encuentra atrapado en su propio pasado: "Cuando volví, Rosita Pazos / me cobijó entre sus brazos. / Me enamoré en un segundo, / ella intentó cambiar mi mundo. / Lo que su amor no conocía / es que la guerra nos asesina. / (...) te juro que no es con vos, / soy un soldado". De la guerra no se vuelve, ser soldado parece asumir la persistencia de una identidad definitiva.

\section{¿Jóvenes terneros o gloriosos combatientes?}

Las representaciones acerca de la identidad de los combatientes han constituido uno de los nudos fundamentales que ha atravesado los debates sobre Malvinas (Lorenz, 2015), incluso en el seno mismo de los veteranos de guerra. Como hemos visto, estas maneras de ver a los soldados se articulan con las lecturas dictatorial y heroica señaladas por Guber (2021). En el corpus analizado, la figura del ex combatiente como "víctima" es la que prevalece: sea porque ir a una guerra obligado lo convirtió víctima; sea porque la Argentina no podía de ninguna manera vencer a la segunda potencia de la OTAN ${ }^{13}$ sea porque se trató de jóvenes inexpertos y desguarnecidos, enviados a una guerra absurda al servicio de la dictadura; sea porque en las islas se continuaron practicando los abusos y las torturas que los militares desplegaban en el continente. ${ }^{14}$

Uno de los modos en los que se construye esa figura de víctima, asociada a la lectura dictatorial, es a través de las imágenes que representan al combatiente como "hijo", lo asocian a la infancia y, como atributos de la misma, a la ingenuidad y a la inocencia: "Madre me voy a la isla, no sé contra quién pelear (...) / con el casco y con las botas, ni siquiera sé marchar", escribe Lerner (1983). Las referencias a "los chicos” y "los pibes” (García, 1982), los "jóvenes terneros" que serán ofrendados en sacrificio (Virus, 1982) o afirmaciones como "mandan 
a los chicos / para que los masacren" (Flema, 1998) confinan al combatiente al lugar pasivo de quien fue arrojado sin propia voluntad a la guerra: "Te sacaron de lo hondo de la selva / o de algún potrero ingenuo y olvidado. / Te sacaron de tu casa y sin abrigo / te largaron en el viento sur helado" (Ciro y los Persas, 2012). Aún en los casos en que se le reconoce un rol activo en la contienda, se lo vincula a la inocencia de la infancia: “soldaditos de plomo" (Heredia, 1983), "niño guerrero" o "soldado niño" (Tren Loco, 2008).

Sin embargo, en esta última canción aparece una figura minoritaria en torno a esta representación de los ex combatientes: son "Hombres de solo 18 años". A través del reconocimiento condensado en "hombres" se restituye la capacidad de agencia y, como consecuencia, el sentido de la lucha: "Te fuiste al sur / Con tantos hijos de ese pueblo / a combatir con frío mar / Hombres de solo 18 años / por las Malvinas a luchar". Emerge así una representación que le asigna una identidad "heroica" al combatiente, en claro contraste con la figura de "víctima". Al sentimiento de lástima atribuido a la sociedad en la primera interpretación se contrapone el sentimiento de orgullo. De esta manera, se afirma que el sacrificio no fue en vano, en el marco de una guerra absurda, sino que, tal como señalamos más arriba con "El Visitante" y "Memorias de la guerra", tuvo un sentido: "Sin temerle al enemigo / cuya alegría es robar y matar / sin pensar en nada más que / defender su hogar / y a su patria que tanto amó / y en sacrificio / entregarse al sol / y defender Malvinas" (Tren Loco, 2008). Del mismo modo, en "Nido de águilas" (1996) de Malón, la figura del soldado caído, al expresar una causa y un sentimiento justos, aparece vinculada a una épica de lo heroico: "el ejemplo ungido en dolor / heroico caído en tierra / por la patria que tanto amó". En "1982” (1985) la banda de metal Apocalipsis refuerza esa representación: "Nunca se olviden de la gente que luchó / y murió allá en Malvinas / Los gloriosos combatientes en el sur".

Asociada a la lectura heroica, la reivindicación del sentido de la lucha y del valor de los ex combatientes empalma con las representaciones que sostienen el carácter justo de la Causa Malvinas: "Levante el pueblo una bandera / por la paz o por la guerra, / por la mentira o la inocencia, / que defendió nuestras fronteras. / Hoy seremos los soldados / peleando una nueva guerra / contra el olvido y la vergüenza / contra el dolor e indiferencia" (Cielofinal, 2000). Como consecuencia, se configuran miradas que cuestionan aquellas representaciones reiteradas que atribuyen un carácter absurdo a la guerra. Como hemos planteado al comienzo de este trabajo, la mirada sobre la Causa Malvinas y, en particular, la caracterización de la guerra, se articula con las visiones en torno a las identidades en pugna que pretenden definir a los ex combatientes, tal como se representa en las letras de las canciones analizadas.

\section{APORTES PARA LA CONSTRUCCIÓN DE UN MARCO INTERPRETATIVO ESPECÍFICO}

Tal como hemos pretendido dar cuenta a lo largo de nuestro trabajo, la Guerra de Malvinas ha tenido una presencia significativa en las letras de las canciones del rock nacional. Del análisis de las representaciones en torno a los ejes propuestos, podemos concluir que la caracterización de la guerra se articula estrechamente con las representaciones que se construyen en torno a los ex combatientes y al papel de la sociedad y del Estado. En ese sentido, aunque esto implique perder matices, podemos delinear dos grandes interpretaciones que parten de las representaciones fundamentales analizadas, en tanto huellas del pasado reciente que configuran posmemorias construidas a través de la producción artística y cultural (Hirsch, 1997). Las mismas se enlazan con las lecturas más generales que han sido señaladas acerca de las memorias de Malvinas. La primera se configura a través de la concepción de la guerra como una "aventura militar absurda" (en consonancia con la lectura dictatorial). La segunda se construye en torno a la representación del conflicto como una "gesta popular por la soberanía nacional" (vinculada a la lectura heroica). Para desarrollar el análisis de cada una de estas miradas nos valemos aquí de dos letras de canciones, ya mencionadas en el trabajo, que, más allá del grado de popularidad de cada una y de sus intérpretes, condensan los principales aspectos que confluyen en estas representaciones: "Antihéroes" (DLSO, 1999) y "Héroes de Malvinas" (Ciro y los Persas, 2012). 
Alrededor de la interpretación de la guerra como una "aventura militar absurda" se asocian todas las representaciones que señalan el carácter aventurero (es decir, irresponsable) de la recuperación del 2 de abril de 1982, que derivó en una guerra en la que la Argentina y sus combatientes no tenían ninguna posibilidad frente al poderío inglés respaldado por Estados Unidos y la OTAN. En ese sentido, el reclamo de soberanía argentino sobre las islas puede considerarse injusto o justo. En el primer caso, la actitud argentina se vería agravada por constituir una "invasión"; en el segundo, la Causa Malvinas puede considerarse justa, pero injusto el camino que llevó a la recuperación. Esto se puede deber a que todas las guerras son injustas, a que en esta en particular la Argentina no tenía posibilidad de ganar o a que esta fue decidida por una dictadura militar.

La Guerra de Malvinas, en el seno de esta interpretación, se define esencialmente por su contexto: se trató de una decisión de la dictadura militar, dirigida por un general "borracho", con el objetivo de perpetuarse en el poder, ganándose el respaldo de las masas aprovechando los sentimientos patrióticos en torno a Malvinas. En muchas letras, el papel de los ingleses aparece secundarizado. El conflicto bélico sería un episodio más de la política de la dictadura, e incluso en él se continuaron las prácticas represivas a través de abusos y torturas a soldados conscriptos. Por lo tanto, los soldados que combatieron, por su condición de jóvenes y de inexpertos obligados a ir a la guerra, serían víctimas de la dictadura, incluso asimilables a las del terrorismo de Estado practicado en el continente. Las representaciones en torno a la sociedad se vinculan con una actitud de complicidad con la guerra y de indiferencia con los ex combatientes en la posguerra para luego adquirir la lástima hacia ellos como sentimiento dominante. El predominio de estas representaciones en las letras analizadas puede deberse a su coincidencia con la "'forma correcta' de hablar y escuchar sobre Malvinas" (Guber, 2021), es decir, con la lectura dictatorial, que es hegemónica en las memorias sobre Malvinas.

La canción paradigmática que condensa esta visión es "Antihéroes" (1999) de DLSO. En ella se expresan las representaciones propias de la "aventura militar absurda”. "Aquel 2 de abril comenzó la guerra”: la elección de esta fecha como comienzo del conflicto bélico implica suponer implícitamente que la recuperación de las Malvinas fue, en realidad, una invasión, un acto de guerra. Es decir, no fue una gesta soberana, sino una acción beligerante de la dictadura, lo cual le quitaría responsabilidad al Reino Unido en su intento por reconquistarlas a partir del 1 de mayo de 1982. "Con 18 años fuimos a luchar": aquí se señala lo extremadamente joven de los combatientes y, como hemos visto, su inocencia. Esta cantidad de años reaparece en varias letras y constituye uno de los tópicos con mayor arraigo en el imaginario social. 15 "A Margaret Thatcherse le caía el gobierno / y las Islas Malvinas le cayeron del cielo": estos versos refuerzan las causas exógenas para explicar la guerra, la decisión de Galtieri fue útil para la primera ministra inglesa cuyo gobierno tenía profundos problemas políticos y económicos. "Un león bien armado defendía su imperio / nuestros pibes descalzos y en medio del desierto / los fusiles no andaban, las cosas no llegaban / y Galtieri chupaba otro Whisky más": en este caso se enfatiza la desigualdad de fuerzas entre el Reino Unido y la Argentina. Resulta poderosa esta construcción de la imagen de "nuestros pibes descalzos y en medio del desierto", 16 puesto que refuerza ese destino impuesto y desolador para las víctimas de un general que, mientras mandaba a los jóvenes a morir, solamente se dedicaba a beber desde la comodidad del poder. El resultado de la guerra es definitivamente trágico y en vano: "Perdimos tantas vidas por un par de islas / firmando decretos de amnesia general". Este "olvido" hace referencia al de la sociedad que, de algún modo, fue "cómplice" de aquella dictadura, y luego se refugió en una desmemoria autoindulgente. Ni siquiera, entonces, el gol (con la mano) de Maradona a los ingleses puede ser reparador para los ex combatientes: "la mano de Dios no apagó mi dolor / la guerra del olvido fue la que nos mató / la mano de Dios no apagó mi dolor / gritan los antihéroes del ' 82 ". La representación del soldado combatiente como víctima es tan profunda en esta canción que son nominados directamente como "antihéroes": no hubo causa ni sentido para su lucha y su sacrificio.

La segunda interpretación, a la que conceptualizamos como "gesta popular por la soberanía nacional", parte de reivindicar el carácter justo de la lucha frente a la ocupación inglesa. Las representaciones que 
se articulan en esta interpretación son significativamente minoritarias en las letras analizadas. Esto puede deberse a su coincidencia con la lectura heroica que, como hemos visto, constituye una mirada subalterna en la mayoría de los discursos y relatos circulantes sobre Malvinas. Su posición defensiva, en el marco de la disputa por los sentidos en el campo cultural, puede ser considerada como contrahegemónica.

En esta segunda interpretación, se busca distinguir entre la dictadura (y su línea política y militar) y el derecho de la Argentina a recuperar una parte de su territorio usurpado por el imperialismo británico. De este modo, el contexto dictatorial aparece como secundario y la justeza de la causa como el aspecto principal; la guerra se produjo a partir del intento de reconquista por parte de Gran Bretaña. Por lo tanto, los que combatieron por esa causa y con ese sentido, serían "héroes" de una "gesta". En las letras, como en la interpretación anterior, se interpela a la sociedad por su "olvido", aunque en este caso el reproche refiere al no reconocimiento del sacrificio y del valor de los combatientes durante la guerra. Por las mismas razones, se cuestiona al Estado. Esta interpretación atribuye un valor positivo al sentido de la lucha por la recuperación de las islas, al enfrentamiento con Gran Bretaña por esa causa y al desempeño "heroico" de los combatientes. Asimismo, se distingue a los altos mandos y a los representantes del poder dictatorial, por un lado, y a quienes efectivamente combatieron, por el otro.

Como mencionamos, la canción paradigmática que condensa estas representaciones subalternas es "Héroes de Malvinas" (2012) de Ciro y los Persas. Sus versos se preocupan por separar tajantemente a la dictadura y sus intereses ("la basura indefinible de esa escoria que soñó con perpetuarse en la Rosada") de los que combatieron en la guerra. Se manifiesta en esta canción una nueva línea divisoria trazada entre quienes combatieron dignamente y quienes no, especialmente distinguiendo a los ex combatientes de los militares de la dictadura ("los jefes argentinos"). En la letra se reconoce la imposición de ir a luchar que pesó sobre los soldados conscriptos, cuyos orígenes son profundamente populares ("Te sacaron de lo hondo de la selva / o del algún potrero ingenuo y olvidado / te sacaron de tu casa y sin abrigo / te largaron en el viento sur helado"); las dificultades técnicas y la falta de instrucción militar ("Los ingleses que venían preparados"; "Te entregaron armas que no conocías / que con suerte cada tanto funcionaban”); la soledad, el hambre, el frío y el temor ante una situación tan riesgosa y traumática como es una guerra, en la que el miedo a la muerte los "hermana" ("En un hoyo que cavaste / repetías las canciones que creías olvidadas / No sabías qué era sentirte tan lejano / ni que el hambre se comiera tus entrañas, / sólo estaba la mirada de un hermano / con la misma incertidumbre en la mirada); y los abusos que algunos oficiales y suboficiales cometieron contra soldados ("Me pregunto qué pasaba por la mente / del infame que te estaqueaba en el frío"). Asimismo, se destaca el peso que la falta de reconocimiento social tuvo sobre los ex combatientes ("Puede más la indiferencia de tu gente / que la bala más voraz del enemigo"), e incluso su influencia en los suicidios producidos durante la posguerra ("Hubo menos héroes muertos en el frente / que en el campo de batalla del olvido"). Aquí vuelve a aparecer, una vez más, esta representación del "olvido" en la posguerra como una herida aún más dañina que las producidas en la propia experiencia bélica.

Como vemos, la apreciación de algunos de estos aspectos en la letra coincide con las representaciones atribuidas a la "aventura militar absurda", aunque no conlleva las mismas conclusiones. En ese sentido, si bien esta canción puede ser considerada como una síntesis, en tanto asume la coexistencia conflictiva de diversas representaciones, prevalecen en ella los sentidos que se articulan en la lectura heroica. De hecho, las representaciones que se corresponden con la "gesta popular por la soberanía nacional" buscan distinguir a la Causa Malvinas y la lucha soberana, por un lado, de la dictadura, por otro. Al respecto, la letra también destaca el carácter profundamente federal de la composición de los combatientes y el sentido y valor que tuvo lo que fueron a hacer, en las condiciones que lo hicieron: "De Corrientes, Buenos Aires y del Chaco / desde Córdoba, Mendoza, de La Pampa / desde todas las provincias argentinas / los llevaron para hacer una patriada. / Y coraje fue lo que ellos demostraron / frente a 1, 2, 3, 4 enemigos”. Se configura así una resistencia a la representación hegemónica de los ex combatientes como "víctimas". El coraje y el sacrificio, fundamentalmente el de los caídos, tuvo un sentido y una causa justa que lo movilizó: "Y allá quedarán eternos 
centinelas / sin relevo esperando que algún día / sin que corra sangre / vuelva la celeste y blanca a flamear sobre esas tierras argentinas". Los combatientes caídos son "centinelas sin relevo", es decir, su presencia tiene un sentido, no es pasiva, son de algún modo "custodios” de la soberanía argentina. Por último, aparece la perspectiva de recuperar las islas sin derramamiento de sangre, pero reafirmando siempre la soberanía. En ese marco, los ex combatientes, lejos de ser víctimas, son "Héroes" y son "nuestros": "Por siempre serán héroes, por siempre serán héroes / por siempre nuestros héroes de Malvinas".

Como hemos tratado de demostrar, la intensa y contradictoria presencia de la Guerra de Malvinas y sus implicancias en las letras del rock nacional, como expresión de la cultura popular, se encuentra atravesada por representaciones que se articulan con las disputas por el sentido de los actores, de los procesos históricos (políticos y sociales) y de las perspectivas, significados e interpretaciones de una problemática aún vigente como es la Cuestión Malvinas. Hemos pretendido aportar una primera aproximación al análisis de estas representaciones, en tanto huellas de memoria y llaves para pensar la configuración cultural de Malvinas. A partir de ellas, propusimos un marco interpretativo específico e indagamos en el carácter hegemónico y contrahegemónico de las representaciones en pugna. Quedan pendientes desarrollos ulteriores profundizando estos primeros aportes.

\section{REFERENCIAS}

Alabarces, P. (1993). Entre gatos y violadores: El rock nacional en la cultura argentina. Buenos Aires: Colihue.

Archivo Histórico RTA. (28 de octubre de 2015). Galtieri en la Plaza de Mayo: "si quieren venir, que vengan", 1982 (fragmento II) [Archivo de video]. Disponible en https://www.youtube.com/watch?v=QFp5X1KzPGU

Buch, E. y Juárez, C. (2019). Músicos y Malvinas. La cultura de guerra en la Argentina. Nuevo Mundo. Mundos Nuevos. Recuperado de http://journals.openedition.org/nuevomundo/76091

Cisilino, J. (2018). ¿Héroes Nacionales? ¿Víctimas de la dictadura? La disputa por el sentido y la identidad de los caídos y los veteranos de guerra en el debate sobre el reconocimiento de restos en Malvinas. Cuadernos de Marte, 9(15), 209-246.

Cisilino, J. y Barrena, F. (2019). La Guerra de Malvinas en el rock nacional. Recuperado de http://sedici.unlp.edu.a $\mathrm{r} /$ handle/10915/119216

Cisilino, J., García Larocca, M. y Garriga Olmo, S. (2020). "Si quieres saber cómo te fue en la guerra, pregúntale a tu enemigo”. A portes británicos para repensar la guerra de Malvinas. Cuadernos de Marte, 11(18), 424-456.

Di Cione, L. (2015). Rock y dictadura en la Argentina: reflexiones sobre una relación contradictoria. Afuera. Estudios de critica cultural, 10(15).

Flachsland, C. (2007). Una banda de sonido para Malvinas. Puentes, 7(20), 56-62.

Favoretto, M. (2014). La dictadura argentina y el rock: enemigos íntimos. Resonancias, 18(34), 69-87.

Grimson, A. (2011). Los límites de la cultura. Críticas de las teorias de la identidad. Buenos Aires: Siglo Veintiuno.

Guber, R. (2001). ¿Por qué Malvinas? De la causa nacional a la guerra absurda. Buenos Aires: Fondo de Cultura Económica.

Guber, R. (12 de junio de2021). Malvinas. ¿"Gesta” o "aventura absurda”? Dos lecturas que conviene dejar atrás. La Nación. Recuperado de https://www.lanacion.com.ar/ideas/malvinas-gestao-aventura-absurda-dos-lecturas-qu e-conviene-dejar-atras-nid12062021/

Hall, S. (1984). Notas sobre la deconstrucción de "lo popular". En R. Samuel (Ed.), Historia popular y teoría socialista (pp. 93-112). Barcelona: Grijalbo.

Hall, S. (Ed.). (1997). Representation: Cultural Representations and Signifying Practices. Londres: Sage Publications.

Hirsch, M. (1997). Family frames: photography, narrative and postmemory. Cambridge: Harvard University Press. 
Intelectuales cuestionaron la conmemoración oficial del 2 de abril. (30 de marzo de 2012). La Nación. Recuperado de https://www.lanacion.com.ar/politica/intelectuales-cuestionaron-la-conmemoracion-oficial-del-2-de-abrilnid 1461002

Lorenz, F. (2006). Las Guerras por Malvinas. Buenos Aires: Edhasa.

Lorenz, F. (2015). Ungidos por el infortunio. Los soldados de Malvinas en la post dictadura: entre el relato heroico y la victimización. Cuadernos de Historia. Serie economia y sociedad, (13/14), 265-287.

Pujol, S. (2007a). Rock y dictadura. Crónica de una generación (1976-1983). Buenos Aires: Booket.

Pujol, S. (2007b). Era en abril. Puentes, 7(20), 65. Recuperado de https://www.comisionporlamemoria.org/archivos /puentes/20puentes.pdf

Pujol, S. (2015). El rock en la encrucijada. Apuntes para una historia cultural de Malvinas. En Composición libre. La creación musical argentina en Democracia. La Plata: EDULP.

Tenembaum, K. (Productor) y Kamin, B. (Director). (1984). Los chicos de la guerra [Película]. Argentina: K Films / Instituto Nacional de Cinematografía.

Thompson,J. (1987). No picnic (no fue un paseo). La actuación de la 3a Brigada de Comandos de Infantería de la Marina Británica en la guerra de Malvinas. Buenos Aires: Atlántida.

Una visión alternativa sobre la causa de Malvinas. (23 de febrero de 2012). La Nación. Recuperado de https://www.l anacion.com.ar/1450787-una-vision-alternativa-sobre-la-causa-de-malvinas

Vassallo, S. (2020). Marcas de Malvinas en el paisaje. Resistencias populares frente a la desmalvinización oficial. En Godoy, C. y Gómez, M. (Comp.), Pensamientos nuestroamericanos en el siglo XXI: aportes para la descolonización epistémica. Lanús: De la UNLa.

Vassallo, S. y Natalizio, J. F. (2021). Malvinas: Las voces de la plaza. Recuperado de https://www.megafonunla.com. ar/notas/2021-04-13_malvinas-las-voces-de-la-plaza

Vila, P. (1987). Rock nacional and dictatorship in Argentina. Popular Music, 6(2), 129 - 148.

Williams, R. (1988). Cultura. En Marxismo y Literatura. Barcelona: Península.

\section{Notas}

1 El título del presente trabajo alude a la conocida canción "Solo le pido a Dios" de León Gieco. Si bien fue editada en 1978, en el clima beligerante que propició el entonces gobierno dictatorial contra Chile por el Canal de Beagle, nos permitimos el desplazamiento contextual en pos del juego retórico.

2 Este vínculo ha sido abordado en distinto grado por diversos autores, véase Alabarces, 1993; Pujol, 2007a y 2015; Flachsland, 2007; Favoretto, 2014; Di Cione, 2015; Buch y Juárez, 2019; Vila, 1987. Por razones de espacio, el diálogo con esta bibliografía ha sido abordado en una primera aproximación a este análisis (Cisilino y Barrena, 2019).

3 En pos de privilegiar el análisis del corpus, hemos circunscripto el marco teórico. Para mayor desarrollo, ver Cisilino y Barrena (2019).

4 A lo largo del artículo, cuando hablamos de "Causa Malvinas" nos referimos a todos aquellos aspectos vinculados con la disputa de soberanía y el reclamo argentino, incluyendo los sentidos que, como demuestra Guber (2001), fueron convirtiendo una histórica reivindicación de soberanía en una causa popular; mientras que con "Cuestión Malvinas" nos referimos al abordaje académico de esta problemática en tanto vértice articulador de un conjunto amplio de aspectos y perspectivas.

5 Cabe destacar que, en esta primera aproximación, solo nos centraremos en las representaciones presentes en el contenido de las letras; sus autores, géneros musicales y contextos sociales de producción quedan por fuera de los límites del presente artículo.

6 Fuentes utilizadas en el presente trabajo (en orden cronológico): "El banquete" (1982) de Virus, "No bombardeen Buenos Aires" (1982) de Charly García, "Comunicado 166" (1982) de Los violadores, "Deseando destruir y matar" (1983) de V8, "Reina Madre" (1983) de Raúl Porchetto, "Aquellos soldaditos de plomo" (1983) de Víctor Heredia, "La isla de la buena memoria" (1983) de Alejandro Lerner, "Decisiones apresuradas" (1985) de Fito Páez, "1982" (1985) de Apocalipsis, "Gente del sur” (1985) de Rata Blanca, "Cuá Cuá Amén” (1987) de Patricio Rey y sus Redonditos de Ricota, "2 de abril" (1994) de Attaque 77, "Memorias de la Guerra" (1994) de Embajada Boliviana, "Amor suicida" (1994) de 2 minutos, "Nido de almas" (1996) de Malón, "No quiero ir a la guerra" (1998) de 
Flema, "No volvieron más" (1998) de Callejeros, "El visitante” (1999) de Almafuerte, “Antihéroes” (1999) de Don Lunfardo y el Señor Otario, "La casa desaparecida” (1999) de Fito Páez, "Maniobras de Guerra” (2000) de Tren Loco, "Malvinas" (2000) de Cielofinal, "Para la vida" (2006) de León Gieco, "Qué es Dios" (2008) de Las pastillas del abuelo, “Acorazado Belgrano" (2008) de Tren Loco, "Héroes de Malvinas (2012) de Ciro y los persas y "La canción del soldado y Rosita Pazos (2013) de Fito Páez.

7 Once de las veintisiete canciones fueron editadas en los años ochenta (incluyendo el registro en vivo disponible de "Cuá Cuá Amén” en 1987); nueve en los noventa (las primeras recién en 1994); y siete luego del año 2000. Aunque relevamos hasta el 2020, la última canción hallada data de 2013, poco después del trigésimo aniversario de la guerra. En esta primera etapa de nuestra investigación nos centraremos en el análisis sincrónico del corpus propuesto, queda pendiente para un futuro trabajo el análisis diacrónico de las canciones, articulado con sus contextos sociales de producción.

8 Aludimos a nociones de sentido común expresadas en las canciones: por un lado, acerca del papel que jugó "la sociedad”, en términos de actitudes sociales, ante la derrota en la guerra y ante los ex combatientes durante la posguerra; y por otro, acerca de las respuestas estatales de los sucesivos gobiernos desde 1982 hasta la actualidad.

9 Si bien el festival, organizado por la dictadura, tenía como fin recaudar fondos y apoyo para sostener el esfuerzo bélico, su lema, así como numerosas representaciones condenatorias de la guerra analizadas en el presente trabajo, puede haber estado influenciado por el motivo pacifista, de gran arraigo en el movimiento del rock.

10 Para un análisis sobre las plazas de Malvinas, ver Vassallo y Natalizio (2021).

11 Se suele presentar el apoyo de amplios sectores populares a la recuperación de las islas como un respaldo directo a la dictadura (incluso se la contrapone a la masiva movilización del 30 de marzo convocada por la CGT). En el discurso completo de Galtieri del 10 de abril, puede verse cómo cuando afirmaba "les presentaremos batalla" había una ovación en la Plaza de Mayo y cómo cuando hacía referencia a sí mismo como "presidente de los argentinos" era silbado y abucheado, al punto de tener que hacer pausas en su alocución. Ver Archivo Histórico RTA, 2015.

12 La discusión sobre este término excede nuestro trabajo; se trata de una categoría nativa, común a los ámbitos de ex combatientes y "malvineros", que ha sido empleada, a su vez, desde diversas perspectivas en abordajes académicos sobre la Cuestión Malvinas.

13 Para una problematización de estas visiones a partir del análisis de los testimonios de los jefes militares británicos, ver Cisilino y otros, 2020.

14 Para un análisis de esta interpretación a partir del debate en torno al reconocimiento de restos en el Cementerio de Darwin, ver Cisilino, 2018.

15 La mayoría de los soldados conscriptos eran clase '62 y ‘63, es decir, contaban con veinte y veintiún años al momento de la guerra.

16 Paradójicamente, el general Julian Thompson,jefe de la $3^{\circ}$ Brigada de Comandos de la Infantería de la Marina Británica, sostuvo que "el artículo más preciado entre los despojos de guerra dejados por los argentinos hayan sido los excelentes borceguíes que sirvieron para reemplazar al gastado y húmedo calzado que tenía la mayor parte de la Brigada de Comandos" (Thompson, 1987, p. 235) 